\title{
The processes that threaten Indonesian plants
}

\author{
Sugeng Budiharta, Didik Widyatmoko, IraWATi, HaR r Wiriadinata \\ Rugayah, Tukirin Partomihardjo, Ismail, TAHAN Uji, ARY Prihardhyanto \\ KEIM and KERRIE A. WILSON
}

\begin{abstract}
The processes that threaten 240 Indonesian threatened plants were identified and categorized based on a comprehensive review of the published literature and elicitation of information from experts. Intrinsic biological factors and habitat loss are the major causes of plant endangerment in Indonesia (affecting 83 and $82 \%$ of species respectively), followed by overexploitation (64\%) and natural factors $(6 \%)$. The dominant threats vary between major plant groups, with habitat loss being particularly important for palms and trees, and biological factors important for orchids. For all studied plant species three sets of inter-related threatening processes (threat syndromes) were identified that differed among the major plant groups. By identifying and evaluating the processes that threaten plants in Indonesia we provide knowledge to guide their future conservation.
\end{abstract}

Keywords Biodiversity hotspot, Indonesia, overexploitation, threatened plants, threatening processes

This paper contains supplementary material that can be found online at http://journals.cambridge.org

\section{Introduction}

$\mathrm{n}$ the past 500 years 87 vascular plant species have been officially recorded as extinct globally and 28 species are now assumed to be extinct in the wild (IUCN, 2008a). In the past 20 years 12 plant species have gone extinct globally as a result of habitat loss, invasive species and diseases (Baillie et al., 2004). There was a marked increase in the number of plant species categorized as Critically Endangered, Endangered or Vulnerable between 2000 and 2008

Sugeng Budiharta* and Kerrie A. Wilson (Corresponding author) School of Biological Sciences, The University of Queensland, St Lucia, Queensland 4072, Australia. E-mail k.wilson2@uq.edu.au

Didik Widyatmoko Cibodas Botanic Garden, Indonesian Institute of Sciences, Sindanglaya Cipanas, Cianjur, West Java, Indonesia

IRAWATI Bogor Botanic Garden, Indonesian Institute of Sciences, Bogor, West Java, Indonesia

Harry Wiriadinata, Rugayah, Tukirin Partominardjo, Ismail, Tahan Uji and Ary Prihardhyanto Keim Herbarium Bogoriense, Research Center for Biology, Indonesian Institute of Sciences, Bogor, West Java, Indonesia

${ }^{*}$ Current address: Purwodadi Botanic Garden, Indonesian Institute of Sciences, Pasuruan, East Java, Indonesia

Received 26 February 2010. Revision requested 6 May 2010.

Accepted 11 June 2010.
(2,710 newly listed species; IUCN 2000, 2008a). This apparent accelerating rate of endangerment is to some extent a result of improved knowledge but is also an important indicator of the impact of human activities on the persistence of species in the wild (Pimm \& Raven, 2000). Many threatened plants, such as timber trees, palms, ornamental orchids and medicinal plants, also have high commercial value and therefore their extinction will entail not only ecological impacts but also have socio-economic implications (Baillie et al., 2004).

Given the variety of processes that threaten biodiversity a range of conservation strategies are required to slow the rate of species extinction. One task is to evaluate the processes that threaten species so as to facilitate an assessment of risks and inform the prioritization of conservation spending (Lamoreux et al., 2003; Mace et al., 2007). Such analyses provide opportunities for the efficient use of limited resources by targeting specific strategies to abate the dominant threats to species persistence (Wilson et al., 2007).

Habitat loss has been recognized as the most important threat to species globally (Wilson, 1992). However, countryspecific causes of species endangerment have also been identified, including overexploitation in China (Yiming \& Wilcove, 2005), invasive species in the USA (Wilcove et al., 1998) and small population sizes and restricted ranges in Australia (Burgman et al., 2007). While these studies represent countries with diverse economic and biological characteristics, similar analyses have not been undertaken in any nation with a developing economy that is also classified as a biodiversity hotspot, despite such countries being a high priority for conservation efforts (Myers et al., 2000; Brooks et al., 2006).

Indonesia is one of 17 mega-biodiverse countries (Mittermeier et al., 1997) but is facing a rapid loss of biodiversity (Bappenas, 2003; Sodhi et al., 2004). In terms of floristic richness Indonesia ranks fifth, with $>38,000$ plant species, c. 18,700 of which are endemic (Bappenas, 2003). Other than the tropical Andes, Indonesia has the greatest number of endemic plant species in any region $(>6 \%$ of the total global flora; Myers et al., 2000). The unique biodiversity of Indonesia is under pressure from high rates of habitat modification, deforestation, overexploitation, forest fires, and illegal harvesting and trade as a consequence of rapid economic development, high population growth and corrupt institutions (Bappenas, 2003; Sodhi et al., 2004). In Indonesia c. 50\% of forest cover has been lost in the last 50 years, with cover reduced from c. 162 
million ha in 1950 to 86 million ha in 2003 (FWI/GFW, 2002; Indonesian Ministry of Forestry, 2005). Over the last decade the rate of deforestation in Indonesia is estimated to have been 1.8 million ha per year, predominately from timber extraction, transmigration, agricultural expansion, plantation establishment and mining (FWI/GFW, 2002; Bappenas, 2003; Indonesian Ministry of Forestry, 2005). A study of the processes that threaten Indonesian plants is therefore critical to assist with their conservation but research on this topic in Indonesia is rare (Sodhi \& Liow, 2000; Sodhi et al., 2004; Meijaard \& Sheil, 2007a).

Our aim here is to identify and evaluate the processes that threaten plants in Indonesia. We do this by defining, categorizing and quantifying the threatening processes to reveal the major causes of plant endangerment. We also analyse threat syndromes (sensu Burgman et al., 2007), defined as a subset of processes that simultaneously threaten multiple species, to evaluate the interrelationships amongst threats to plants in Indonesia.

\section{Methods}

The primary source of data for this study is Mogea et al. (2001), which provides an account of 240 plant species evaluated by nine Indonesian botanists. The list was an outcome of the Biodiversity Collection Project conducted between 1994 and 2000 and facilitated by the Global Environment Facility and the Research Centre for Biology of the Indonesian Institute of Sciences. Despite representing only a sample of Indonesian plant diversity, this list represents the most comprehensive list of rare and threatened plants in Indonesia. Rare plants were defined as native plants pressured by direct and indirect threats that are causing population decline or species extinction (Mogea et al., 2001). The 240 species are taxonomically diverse and cover all areas of Indonesia.

The composition of the evaluated plants differs markedly from that in the IUCN Red List for Indonesia, which comprises 687 threatened plant species of which only 21 are on both lists (IUCN, 2008b). Palms and orchids dominate Mogea et al. (2001) whereas the IUCN Red List contains only six palm species and no species of orchid. The differences between the nationally-derived list and the globally maintained database are probably because of the differences in spatial scale, experts, taxonomy and the frequency of information update of each database (Burgman, 2002; Possingham et al., 2002). For 671 species on the IUCN Red List the conservation status was last updated in 2000 or before, with only 16 species updated after 2001 (IUCN, 2008b). We consider the Mogea et al. (2001) list of threatened species a more comprehensive and accurate source of information for a country-level analysis.

We categorized the proximate (i.e. direct) threatening processes to each of the 240 species using the IUCN-CMP
Unified Classification of Direct Threats (Hilton-Taylor et al., 2006). Four general threat classes were identified: habitat loss, overexploitation, intrinsic biological factors and natural factors (Table 1). Within the four general threat classes we identified 16 specific threats that are potentially important in the context of Indonesia.

We allocated each plant to one of five groups: palms (Arecaceae, 60 species), orchids (Orchidaceae, 52 species), trees ( 57 species), shrubs (41 species) and others (30 species; Appendix 1). Of the Arecaceae and Orchidaceae 22 and 8 genera, respectively, were evaluated (Uhl \& Dransfield, 1987; IUCN/SSC Orchid Specialist Group, 1996). The tree group evaluated comprises 21 families and 35 genera. The shrub (defined as a ligneous plant with multiple stems and a height $<7 \mathrm{~m}$; Baumer, 1983) group includes woody climbers and comprises 11 families and 20 genera. The other group is used for the remaining species, in 10 families and 14 genera, predominantly herbaceous and parasitic plants. The categorization of plants by these major groups was undertaken to facilitate the development of conservation strategies specific to each group.

The processes that threaten a species were first determined by expert judgement. Two botanists from the Indonesia Botanic Garden and six botanists from Herbarium Bogoriense undertook the threat assessment for the species with which they are familiar. A score of 1 was assigned to those species considered to be negatively affected by a particular threatening process and $o$ if the threat was considered to have no impact. The expert evaluation is potentially subject to bias and, although focusing on species with which they are familiar reduces this, it is likely to produce a conservative evaluation of the effect of key threatening processes. We therefore crosschecked the expert evaluation with secondary data and available literature, including herbarium specimen databases, journal articles, scientific reports, taxonomic books and official websites (Appendix 2). To maximize the level of repeatability and transparency the final evaluation was determined according to the following process: (1) the threats were allocated by the most experienced expert for each species; (2) the evaluation was adjusted if evidence from the secondary information sources contradicted an expert evaluation of no impact of a particular threat on a species; (3) if evidence from the secondary information sources suggested no impact and this contradicted the expert assessment of there being an impact, then the expert assessment took precedence.

Unweighted Pair Group Method with Arithmetic Mean Analysis (UPGMA; Legendre \& Legendre, 1998) was used to identify sets of specific threats (threat syndromes) that simultaneously affect a large number of species (sensu Burgman et al., 2007). Before being clustered the similarities between threats were calculated using the Bray-Curtis dissimilarity method and the distance of the resultant 
TABle 1 Definitions of general and specific threats.

\begin{tabular}{|c|c|}
\hline General threats & Specific threats \\
\hline Habitat loss (reduction in habitat size \& quality) & $\begin{array}{l}\text { Transmigration (establishment of human settlements) } \\
\text { Development (expansion of urban \& rural settlements, including } \\
\text { the development of roads \& other physical buildings for } \\
\text { commercial \& industrial purposes) } \\
\text { Timber plantation (wood \& pulp plantation establishment; e.g. } \\
\text { Acacia mangium plantation) } \\
\text { Perennial crop plantation (e.g. oil palm, rubber \& coffee } \\
\text { plantation) } \\
\text { Agriculture (e.g. crop land expansion \& fish-pond establishment) } \\
\text { Logging (timber extraction from native forest, including legal } \\
\text { forest concessions \& illegal logging) } \\
\text { Mining (forest clearing for mine site establishment) }\end{array}$ \\
\hline $\begin{array}{l}\text { Overexploitation (removal of individuals from natural habitat for } \\
\text { consumptive uses or because existence is undesirable) }\end{array}$ & $\begin{array}{l}\text { Economic value (harvested because of high economic value) } \\
\text { Cultural use (harvested for cultural value; e.g. traditional } \\
\text { ceremony) } \\
\text { Undesirable (eradicated because of lack of value) }\end{array}$ \\
\hline $\begin{array}{l}\text { Biological factors (specific intrinsic biological characteristics } \\
\text { deeming species susceptible to population decline) }\end{array}$ & $\begin{array}{l}\text { Small population size (the known natural population is }<1,000 \\
\text { adult plants \& sensitive to environmental stochasticity) } \\
\text { Restricted range (found only in a particular area; this definition } \\
\text { includes endemism) } \\
\text { Specific habitat (requires specific types of habitat; e.g. limestone } \\
\text { rocks) } \\
\text { Complex reproduction (complex reproduction mechanism, } \\
\text { including inflorescence structure \& various life stages) } \\
\text { Symbiont requirement (interaction with other species including } \\
\text { parasitism \& mutualism; e.g. specific insect required for } \\
\text { pollination) }\end{array}$ \\
\hline Natural factors (natural stochastic events) & $\begin{array}{l}\text { Natural disturbances (environmental stochasticity; e.g. flood, } \\
\text { wildfire, drought) }\end{array}$ \\
\hline
\end{tabular}

matrix was ordinated using Nonmetric Multi-Dimensional Scaling (Legendre \& Legendre, 1998). To provide a more detailed assessment of threat syndromes we also undertook this analysis for each major plant group. All statistical analyses were conducted using $R$ v. 2.7.2 (R Development Core Team, 2008).

\section{Results}

\section{General and specific threats}

Intrinsic biological factors and habitat loss are the most significant general threats to the 240 species of plants evaluated, affecting 83 and $82 \%$ of species respectively. Overexploitation has also contributed considerably to species endangerment, affecting $64 \%$ of species, whereas natural factors are endangering a relatively small proportion of the studied species (6\%; Fig. 1).

Of the specific threats, restricted ranges and small population sizes are the most prevalent threats, both associated with $65 \%$ of all plants studied (Fig. 1). Other significant specific threats are overexploitation because of high economic value, logging activities, development of human settlements, agriculture and perennial crop plantations. The two threatening processes that were thought to be potentially important in the context of
Indonesia (transmigration and cultural use) were found to endanger plants to a lesser extent ( 9 and $5 \%$ respectively).

\section{Threats by major plant group}

The type of general threat affecting species varies significantly between groups (Fig. 2). Habitat loss is the most important threat to palms (95\%) and trees (98\%), whereas biological factors are the major threat to shrubs (88\%) and the other species investigated (97\%). However, orchids are most adversely affected by overexploitation and biological factors (98 and 100\%, respectively).

Of the specific threats, overexploitation because of economic value and symbiont requirements are the most important threats to orchids (both 98\%), and logging is the major threat to trees (77\%). Palms are threatened mostly by development of human settlements (78\%), and small population size is the most important threat to shrubs $(68 \%)$ and the remaining species investigated (97\%).

\section{Threat syndromes}

Using UPGMA three sets of interrelated threats that concurrently affect a large number of species (threat 


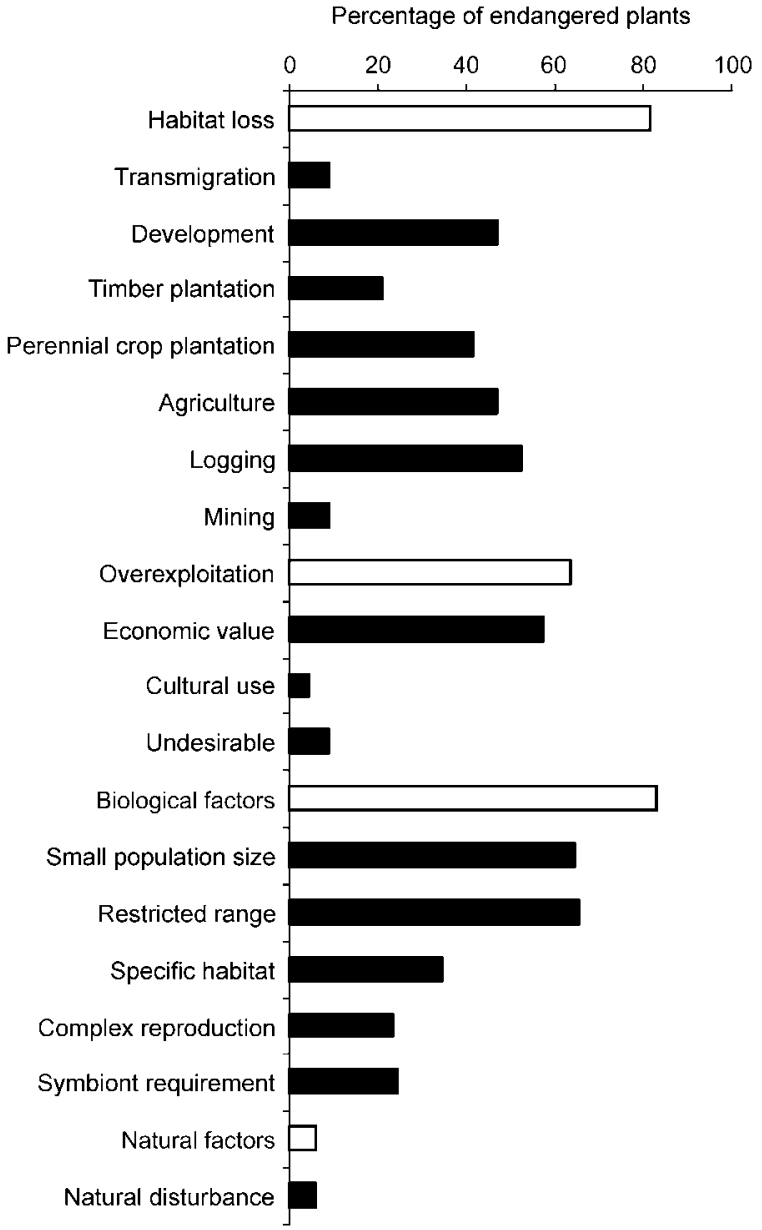

FIG. 1 The percentage of a sample of Indonesian threatened plant species ( $n=240$; Appendix 1) affected by general and specific threats. The white bars represent the four general threats; black bars represent the 16 specific threats. Categories of specific threats are not exclusive and therefore do not total $100 \%$.

syndromes) were identified (Fig. 3): (1) species with small populations that are endemic to particular areas; these are also overexploited because of their economic value and are located in areas that are threatened by logging activities (e.g. Calamus ciliaris, Arecaceae; Phalaenopsis gigantea, Orchidaceae; Upuna borneensis, Dipterocarpaceae); (2) species in natural habitats simultaneously disturbed by agriculture, development for human settlements and perennial crop plantations (e.g. Arcangelisia flava, Menispermaceae; Alyxia reinwardtii, Apocynaceae; Schizostachyum castaneum, Poaceae); (3) species with complex reproduction mechanisms that also have specific habitat requirements and symbiotic relationships with other organisms (e.g. some flagship species such as Amorphophallus spp., Araceae; Rafflesia spp., Rafflesiaceae; Paphiopedilum spp., Orchidaceae).

\section{Threat syndromes by major plant group}

Two sets of inter-related threats were identified for species of orchid (Fig. 4a): (1) species that are overexploited

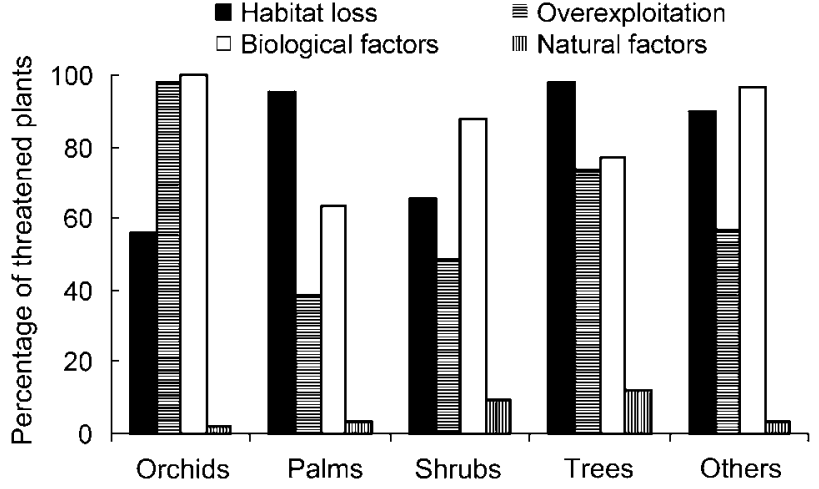

FIG. 2 The percentage of 240 plant species (Appendix 1) affected by the four general threats (habitat loss, overexploitation, biological factors, natural factors) is significantly different among major plant groups $\left(\chi^{2}=32.07, \mathrm{df}=12, \mathrm{P}<0.001\right)$. Five plant groups are represented: orchids $(n=52)$, palms $(n=60)$, shrubs $(n=41)$, trees $(n=57)$ and others $(n=30)$.

because of their economic value and also have restricted ranges, small population sizes, symbiont requirements, complex reproduction mechanisms and specific habitat requirements (e.g. Paphiopedilum kolopakingii, P. mastersianum) or are threatened by logging (e.g. Paraphalaenopsis serpentilingua and Paraphalaenopsis laycockii); (2) species for which their natural habitats are disturbed concurrently by agriculture and development of human settlements (e.g. Phalaenopsis amabilis and Phalaenopsis javanica).

Two threat syndromes were identified for palm species (Fig. 4b): (1) species for which their natural habitats occur in areas important for perennial crop plantations, development of human settlements and logging (e.g. Nenga gajah and Borassodendron borneensis); (2) restricted range

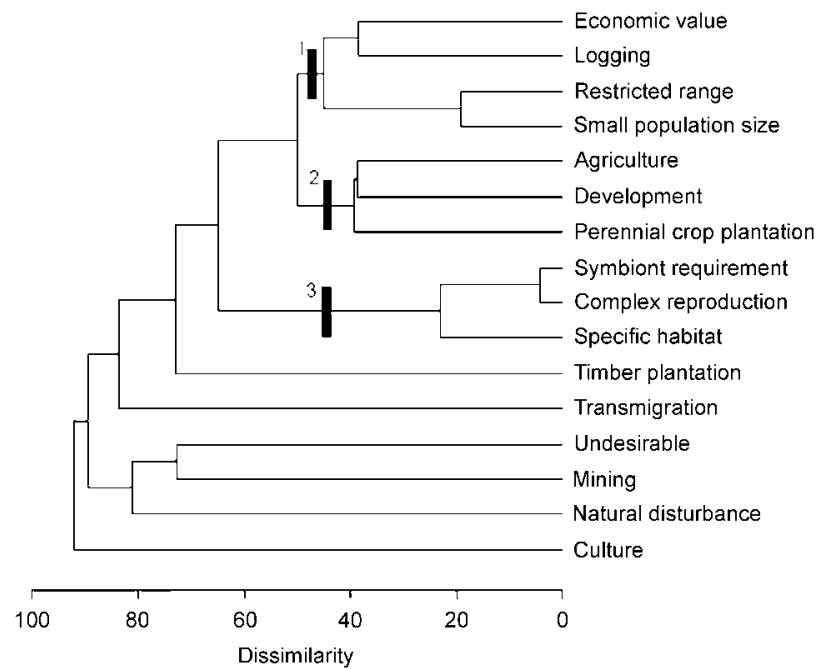

FIG. 3 Dendrogram of threat syndromes to Indonesian plant species. The three threat syndromes are (1) economic value, logging, restricted ranges and small population sizes; (2) agriculture, development and perennial crop plantation; (3) symbiotic requirement, complex reproduction and specific habitat. 


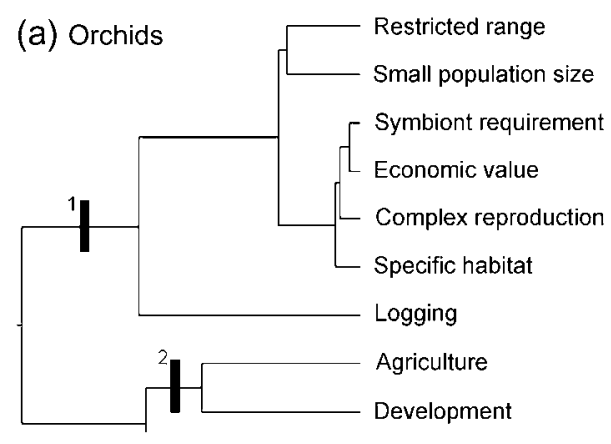

(c) Shrubs

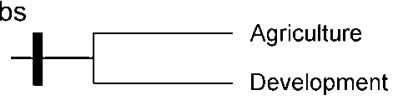

(e) Others

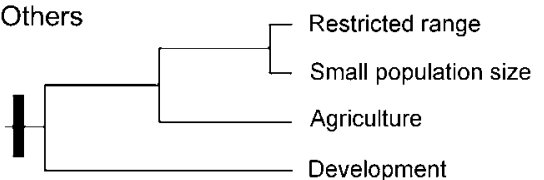

(b)
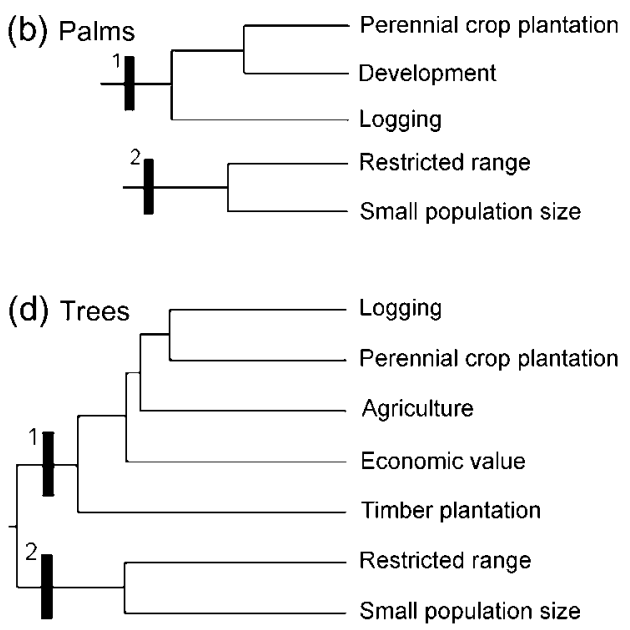

FIG. 4 Dendrogram of the three threat syndromes (Fig. 3) to five groups of plants: (a) orchids; (b) palms; (c) shrubs; (d) trees; (e) others.

species with small population sizes (e.g. Ceratolobus glaucescens and Johannesteijsmannia altifrons).

Only one threat syndrome was identified for shrub species (Fig. 4c): species for which their natural habitats intersect with areas of agriculture and areas of human settlement development (e.g. some species used for traditional medicine such as Anaxagorea javanica, Annonaceae, Rauvolfia serpentina, Apocynaceae).

There are two sets of inter-related threats affecting tree species (Fig. 4d): (1) species that are overexploited and are also threatened by habitat loss because of logging activities, perennial crop plantations, agriculture and timber plantations (e.g. major commercial timber trees such as Shorea spp., Dipterocarpaceae; Diospyros spp., Ebenaceae; Eusideroxylon zwageri, Lauraceae, and also some agarwood species such as Aquilaria spp., Thymelaceae); (2) restricted range species with small population sizes (e.g. Mangifera casturi, Anacardiaceae; Vatica bantamensis, Dipterocarpaceae).

Two threat syndromes were identified for the other species: (1) species with complex reproduction systems that typically have symbiont requirements (e.g. Amorphophallus spp., Rafflesia spp.; this threat syndrome was not represented in the cluster analysis because the coefficient of Bray-Curtis dissimilarity was zero, which reveals a perfect relationship between the threats); (2) restricted range species with small population sizes occurring in areas where habitat has been destroyed for development of agriculture and human settlements (Fig. 4e; e.g. Gigantochloa manggong, Poaceae; Musa acuminata var. nakaii, Musaceae).

\section{Discussion}

Indonesia has high levels of plant endemism but significant socio-economic constraints to the conservation of bio- diversity. In addition to habitat loss, the greatest threat to biodiversity at a global scale (Wilson, 1992; Baillie et al., 2004), overexploitation and intrinsic biological factors (such as restricted ranges and small population sizes), are important threats to plant species in Indonesia. We identified natural factors (such as floods and drought) as a minor cause of endangerment to the plant species evaluated.

Species extinction in tropical biodiversity hotspots is often linked with habitat loss caused by the destruction of primary forests (Brooks et al., 2002, 2003). Our study reveals that logging activities are a major threat to plants in Indonesia. These results concur with the causes of deforestation in Indonesia between 1950 and 2000 being timber extraction (69 million ha), clearing for shifting cultivation (4 million ha), establishment of perennial crop plantations ( 7 million ha), creation of timber plantations (9 million ha), and forest conversion in transmigration areas (4 million ha; FWI/GFW, 2002). The establishment of oil palm Elaeis guineensis plantations is expected to increase species endangerment in the future (Fitzherbert et al., 2008).

In our analysis of threat syndromes habitat loss caused by logging often occurs simultaneously with development of human settlements, agriculture, and perennial crop and timber plantations. This syndrome is dominant for the plants that occur in Sumatra and Kalimantan, the two regions in Indonesia with the most extensive areas of forest concessions, illegal logging, wood plantations for pulp production and oil palm plantations (FWI/GFW, 2002). A combination of development of human settlements and agriculture is the major threat to the plant species evaluated that occur in the centres of human population (i.e. Java and Bali) where threats from other causes of habitat destruction 
are less prevalent. Further spatial analysis of the distribution of species and threats is needed to verify these patterns.

Conventional conservation strategies of creating new protected areas are likely to be important for abating threats caused by habitat loss. However, commitment of the Indonesian government to strengthening the role of existing protected areas by more stringent law enforcement and good governance of these areas will also be essential for conserving such species. The Indonesian government has officially preserved 24 million ha (13\% of the total land area) as protected areas (WRI, 2003) yet the pressures on biodiversity are still high because the reserved areas are threatened by forest fires, illegal logging, mining and establishment of oil palm plantations. Such activities are thought to reduce the effective size of these protected areas by $>50 \%$ (Curran et al., 2004; Gaveau et al., 2007). Prudent decision making is also needed in allocating land-uses, especially if increasing demands for timber and oil palm plantations are to be satisfied. The location of such land uses must be carefully considered in the context of habitat for threatened species (Wilson et al., 2010). Another strategy is to mandate timber and plantation companies to undertake more conservation-friendly management practices and set aside areas within timber concessions such as high conservation value forests (Dennis et al., 2008). Such set-asides are increasingly necessary to certify production forests and oil palm plantations (Meijaard \& Sheil, 2007b; Fitzherbert et al., 2008; Venter et al., 2008).

We found that overexploitation is a substantial threat to the plant species investigated. Conservation strategies such as strict regulation of management practices (e.g. harvesting methods) and trade (e.g. chain of custody and certification) are needed to control the exploitation and utilization of species of economic value (Soehartono \& Newton, 2001).

Restricted ranges and small population sizes were associated with the endangerment of Indonesian plants but the consequences of such traits are expected to be emphasized in Indonesia because of habitat loss and overexploitation. The susceptibility of species with restricted ranges to human-induced disturbance can be mitigated by strictly protecting the remaining habitat of these species, combined with ex situ propagation, reintroduction and population enrichment in natural habitats.

We also found that each group of plants has a different dominant threat syndrome. For orchid species the combination of threats caused by biological factors and overexploitation for economic purposes is common. A combination of financial reward and difficulties associated with propagating these species motivate poachers to harvest orchids in their natural habitats. Epiphytic orchids of the genera Phalaenopsis and Paraphalaenopis are threatened by logging activities because they require host trees. In contrast, terrestrial orchids of the genus Paphiopedilum are relatively protected from threats caused by habitat loss because they are commonly found in specific habitat niches (e.g. limestone rocks, river banks and steep slopes).

The palm and tree species evaluated are threatened simultaneously by overexploitation for economic purposes and habitat destruction caused by logging activities, perennial crop plantations, development of human settlements and agriculture. Compared to orchids, both palms and trees are habitat generalists and are consequently more susceptible to several types of habitat loss. Strong threat syndromes for shrubs are not apparent, except the co-occurrence of threats caused by agricultural activities and development of human settlements. This is presumably attributable to their diverse uses, simple biological characteristics and widespread geographical distribution.

For the remaining herbaceous and parasitic species the threat syndrome is a combination of threatening processes caused by biological factors and habitat loss. Compared to orchids threatened species such as Amorphophallus spp. and Rafflesia spp. are not economically valuable. However, because of their complex reproduction mechanisms and specific habitat requirements such species are sensitive to habitat disturbance, so that even minor habitat destruction will severely affect these species.

Our findings indicate that invasive alien species, pollution, disease and climate change are not important threats to Indonesian plants. In the IUCN Red List no Indonesian plants are listed as threatened by these processes (IUCN, 2008b). Wilson (1992), however, noted that introduced species are the second most important threat to biodiversity after habitat loss. Further research is therefore required on the impacts of invasive alien plant species on the flora of Indonesia (Lawler et al., 2006; Meijaard \& Sheil, 2007a).

In Indonesia there is a lack of information on the processes that threaten native species. This inevitably leads to difficulties in developing conservation policy and setting conservation priorities, and precludes the development of integrated conservation strategies across a wide range of taxonomic groups. This study is the first comprehensive evaluation of a small but representative sample of the plant diversity of Indonesia. We therefore recommend that information on the processes that threaten Indonesian species be expanded and periodically updated, with this research serving as a benchmark and a baseline to evaluate trends through time. In addition, an evaluation of threat syndromes at a local scale (for provinces or protected areas) will help guide the development and implementation of conservation programmes.

\section{Acknowledgements}

This research was supported by a postgraduate Australian Development Scholarship to SB from AusAID and funding to KAW from the Australian Research Council. 


\section{References}

Baillie, J.E.M., Hilton-Taylor, C. \& Stuart, S.N. (eds) (2004) 2004 IUCN Red List of Threatened Species: A Global Species Assessment. IUCN, Gland, Switzerland, and Cambridge, UK.

Bappenas (Badan Perencanaan Pembangunan Nasional) (2003) Indonesian Biodiversity Strategy and Action Plan (IBSAP). The National Development Planning Agency, Jakarta, Indonesia.

B A umer, M. (1983) Notes on Trees and Shrubs in Arid and Semi-arid Regions. Food and Agriculture Organization of the United Nations, Rome, Italy.

Brook, B.W., Sodhi, N.S. \& NG, P.K.L. (2003) Catastrophic extinctions follow deforestation in Singapore. Nature, 424, 420-423.

Brooks, T.M., Mittermeier, R.A., da Fonseca, G.A.B., Gerlach, J., Hoffmann, M., Lamoreux, J.F. et al. (2006) Global diversity conservation priorities. Science, 313, 58-61.

Brooks, T.M., Mittermeier, R.A., Mittermeier, C.G., DA Fonseca, G.A.B., Rylands, A.B., Konstant, W.R. et al. (2002) Habitat loss and extinction in the hotspots of biodiversity. Conservation Biology, 16, 909-923.

Burgman, M.A. (2002) Are listed threatened plant species actually at risk? Australian Journal of Botany, 50, 1-13.

Burgman, M.A., Keith, D., Hopper, S.D., Widyatmoko, D. \& Drill, C. (2007) Threat syndromes and conservation of the Australian flora. Biological Conservation, 134, 73-82.

Curran, L.M., Trigg, S.N., McDonald, A.K., Astiani, D., Hardiono, Y.M., Siregar, P. et al. (2004) Lowland forest loss in protected areas in Borneo. Science, 303, 1000-1003.

Dennis, R.A., Meijaard, E., Nasi, R. \& Gustafsson, L. (2008) Biodiversity conservation in Southeast Asian timber concessions: a critical evaluation of policy mechanisms and guidelines. Ecology and Society, 13, e25.

Fitzherbert, E.B., Struebig, M.J., Morel, A., Danielsen, F., Bruhl, C.A., Donald, P.F. \& Phalan, B. (2008) How will oil palm expansion affect biodiversity? Trends in Ecology \& Evolution, 23, 538-545.

FWI/GFW (Forest Watch Indonesia/Global Forest Watch) (2002) The State of the Forest: Indonesia. Country Report. Forest Watch Indonesia, Bogor, Indonesia, and Global Forest Watch, Washington, DC, USA.

Gaveau, D.L., Handono, W. \& Setiabudi, F. (2007) Three decades of deforestation in southwest Sumatra: have protected areas halted forest loss and logging, and promoted re-growth? Biological Conservation, 137, 495-504.

Hilton-Taylor, C., Stattersfield, A., Salafsky, N., Salzer, D. \& Neugarten, R. (2006) Unified Classification of Direct Threats v. 1.o June 2006. IUCN, Gland, Switzerland, and Cambridge, UK. Http://www.iucn.org/themes/ssc/sis/classification [accessed 7 August 2008].

Indonesian Ministry of Forestry (2005) Indonesian Forestry Outlook 2020. Centre of Planning and Statistics, Indonesian Ministry of Forestry, Jakarta, Indonesia.

IUCN (2000) IUCN Red List of Threatened Species. IUCN, Gland, Switzerland, and Cambridge, UK.

IUCN (2008a) Summary Statistics for Globally Threatened Species. IUCN, Gland, Switzerland, and Cambridge, UK. Http:// www.iucnredlist.org/documents/2008RL_stats_table_3b_ v1223294385.pdf [accessed 15 September 2008].

IUCN (2008b) IUCN Red List of Threatened Species. IUCN, Gland, Switzerland, and Cambridge, UK. Http://www.iucnredlist.org [accessed 15 September 2008].

IUCN/SSC OrChid SpeCialist Group (1996) Orchids-Status Survey and Conservation Action Plan. IUCN, Gland, Switzerland, and Cambridge, UK.
Lamoreux, J., Akcakaya, H.R., Bennun, L., Collar, N.J., Boitani, L., Brackett, D. et al. (2003) Value of the IUCN Red List. Trends in Ecology \& Evolution, 18, 214-215.

Lawler, J.J., Aukema, J.E., Grant, J.B., Halpern, B.S., Kareiva, P., Nelson, C.R. et al. (2006) Conservation science: a 20-year report card. Frontiers in Ecology and the Environment, 4, 473-480.

Legendre, P. \& Legendre, L. (1998) Numerical Ecology: Development in Environmental Modelling. Second English edition. Elsevier Science B.V., Amsterdam, The Netherlands.

Mace, G.M., Possingham, H.P. \& Leader-Williams, N. (2007) Prioritizing choices in conservation. In Key Topics in Conservation Biology (eds D.W. Macdonald \& K. Service), pp. 17-34. Blackwell, Oxford, UK.

MeijaARD, E. \& Sheil, D. (2007a) Is wildlife research useful for wildlife conservation in the tropics? A review for Borneo with global implications. Biodiversity and Conservation, 16, 3053-3065.

Meijaard, E. \& Sheil, D. (2007b) A logged forest in Borneo is better than none at all. Nature, 446, 974.

Mittermeier, R.A., Gil, P.R. \& Mittermeier, C.G. (1997) Megadiversity: Earth's Biologically Wealthiest Nations. CEMEX, Mexico City, Mexico.

Mogea, J.P., Gandawijaya, D., Wiriadinata, H., Nasution, R.E. \& Irawati (2001) Indonesian Rare Plants. Research Center and Development for Biology, Indonesian Institute of Sciences, Bogor, Indonesia.

Myers, N., Mittermeier, R.A., Mittermeier, C.G., Da FonsecA, G.A.B. \& Kent, J. (2000) Biodiversity hotspots for conservation priorities. Nature, 403, 853-858.

Pimm, S.L. \& Raven, P. (2000) Extinction by numbers. Nature, 403, 843.

Possingham, H.P., Andelman, S.J., Burgman, M.A., Medelin, R.A., Master, L.L. \& Keith, D.A. (2002) Limits to the use of threatened species lists. Trends in Ecology \& Evolution, 17, 503-507.

R Development Core Team (2008) R: A Language and Environment for Statistical Computing. R Foundation for Statistical Computing. Http://www.R-project.org [accessed 4 April 2009].

Sodhi, N.S., Koh, L.P., Brook, B.W. \& N G, P.K.L. (2004) Southeast Asian biodiversity: an impending disaster. Trends in Ecology \& Evolution, 19, 645-650.

SodHI, N.S. \& Liow, L.H. (2000) Improving conservation biology research in Southeast Asia. Conservation Biology, 14, 1211-1212.

Soemartono, T. \& Newton, A.C. (2001) Conservation and sustainable use of tropical trees in the genus Aquilaria II. The impact of gaharu harvesting in Indonesia. Biological Conservation, 97, 29-41.

Uhl, N.W. \& Dransfield, J. (1987) Genera Palmarum. L.H. Bailey Hortorium and The International Palm Society, Lawrence, USA.

Venter, O., Meija a R D, E. \& Wilson, K. (2008) Strategies and alliances needed to protect forest from palm-oil industry. Nature, 451, 16.

Wilcove, D.S., Rothstein, D., Jason, D., Phillips, A. \& Losos, E. (1998) Quantifying threats to imperilled species in the United States. BioScience, 48, 607-615.

Wilson, E.O. (1992) The Diversity of Life. Harvard University Press, Cambridge, USA.

Wilson, K.A., Meijaard, E., Drummond, S., Grantham, H.S., Boitani, L., Catullo, G. et al. (2010) Conserving biodiversity in production landscapes. Ecological Applications. 20, 1721-1732.

Wilson, K.A., Underwood, E.C., Morrison, S.A., Klausmeyer, K.R., Murdoch, W.W., Reyers, B. et al. (2007) Maximizing the conservation of the world's biodiversity: what to do, where and when. PLoS Biology, 5, e233.

WRI (World Resources Institute) (2003) Biodiversity and Protected Areas-Indonesia. World Resources Institute, Washington, DC, USA. Http://www.earthtrends.wri.org/pdf_library/country_profiles/ bio_cou_360.pdf [accessed 14 September 2008]. 
Yiming, L. \& Wilcove, D.S. (2005) Threats to vertebrate species in China and the United States. BioScience, 55, 147-153.

\section{Appendices}

The appendices for this article are available online at http:// journals.cambridge.org

\section{Biographical sketches}

SUGENG BUDIHARTA's research interest is the conservation of threatened plants and degraded ecosystems, especially in the tropics.
Didik Widyatmoko's research is focused on the conservation of threatened palms. IRAWATI's research interests are in orchid species and their conservation. HARRY WIRIADINATA is a taxonomist specializing in the Fabaceae and Thymelaceae. RUGAYAHA is a taxonomist specializing in the Cucurbitaceae. TUKIRIN PartomiHARDJO is an ecologist with interests in ecosystem dynamics, especially in degraded forests and volcanic ecosystems. IsmaIL is a field botanist with a special interest in trees. TAHAN $\mathrm{U}_{\mathrm{JI}}$ is interested in species of the Rutaceae and Bombacaceae. ARY PRIHARDhYANTO KeIM has a particular interest in the taxonomy of Pandanaceae. Kerrie A. Wilson's research interests are in conservation decision making. 